\title{
Front Matter: Volume 8636
}

, "Front Matter: Volume 8636," Proc. SPIE 8636, Advances in Slow and Fast Light VI, (29 March 2013); doi: 10.1117/12.2021909

SPIE. Event: SPIE OPTO, 2013, San Francisco, California, United States 


\section{PROCEEDINGS OF SPIE}

\section{Advances in Slow and Fast Light VI}

Selim M. Shahriar

Frank A. Narducci

Editors

3-5 February 2013

San Francisco, California, United States

Sponsored and Published by

SPIE 
The papers included in this volume were part of the technical conference cited on the cover and title page. Papers were selected and subject to review by the editors and conference program committee. Some conference presentations may not be available for publication. The papers published in these proceedings reflect the work and thoughts of the authors and are published herein as submitted. The publisher is not responsible for the validity of the information or for any outcomes resulting from reliance thereon.

Please use the following format to cite material from this book:

Author(s), "Title of Paper," in Advances in Slow and Fast Light VI, edited by Selim M. Shahriar, Frank A. Narducci, Proceedings of SPIE Vol. 8636 (SPIE, Bellingham, WA, 2013) Article CID Number.

ISSN: 0277-786X

ISBN: 9780819494054

Published by

SPIE

P.O. Box 10, Bellingham, Washington 98227-0010 USA

Telephone +1 3606763290 (Pacific Time) · Fax +1 3606471445

SPIE.org

Copyright $@ 2013$, Society of Photo-Optical Instrumentation Engineers.

Copying of material in this book for internal or personal use, or for the internal or personal use of specific clients, beyond the fair use provisions granted by the U.S. Copyright Law is authorized by SPIE subject to payment of copying fees. The Transactional Reporting Service base fee for this volume is $\$ 18.00$ per article (or portion thereof), which should be paid directly to the Copyright Clearance Center (CCC), 222 Rosewood Drive, Danvers, MA 01923. Payment may also be made electronically through $\mathrm{CCC}$ Online at copyright.com. Other copying for republication, resale, advertising or promotion, or any form of systematic or multiple reproduction of any material in this book is prohibited except with permission in writing from the publisher. The CCC fee code is $0277-786 \mathrm{X} / 13 / \$ 18.00$.

Printed in the United States of America.

Publication of record for individual papers is online in the SPIE Digital Library.

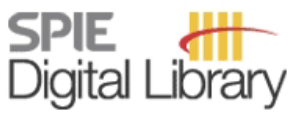

SPIEDigitalLibrary.org

Paper Numbering: Proceedings of SPIE follow an e-First publication model, with papers published first online and then in print and on CD-ROM. Papers are published as they are submitted and meet publication criteria. A unique, consistent, permanent citation identifier (CID) number is assigned to each article at the time of the first publication. Utilization of CIDs allows articles to be fully citable as soon as they are published online, and connects the same identifier to all online, print, and electronic versions of the publication. SPIE uses a six-digit CID article numbering system in which:

- The first four digits correspond to the SPIE volume number.

- The last two digits indicate publication order within the volume using a Base 36 numbering

system employing both numerals and letters. These two-number sets start with 00, 01, 02, 03, 04, $05,06,07,08,09,0 A, 0 B \ldots$. OZ, followed by 10-1Z, 20-2Z, etc.

The CID Number appears on each page of the manuscript. The complete citation is used on the first page, and an abbreviated version on subsequent pages. Numbers in the index correspond to the last two digits of the six-digit CID Number. 


\section{Contents}

vii Conference Committee

ix Introduction

xi Group IV photonics for the mid infrared (Plenary Paper) [8629-1]

R. Soref, The Univ. of Massachusetts at Boston (United States)

xxvii Light in a twist: optical angular momentum (Plenary Paper) [8637-2]

M. J. Padgett, Univ. of Glasgow (United Kingdom)

\section{RESONATORS}

863602 EIT analogs using orthogonally polarized modes of a single whispering-gallery microresonator (Invited Paper) [8636-2]

A. T. Rosenberger, Oklahoma State Univ. (United States)

863604 Compact coupled resonators for slow-light sensor applications (Invited Paper) [8636-4]

W. Guo, M. Digonnet, Stanford Univ. (United States)

INTEGRATED AND SOLID-STATE OPTICS

863607 Slow light through tightly coupled light waves and acoustic waves in nanoscale waveguides (Invited Paper) [8636-7]

Z. Wang, The Univ. of Texas at Austin (United States); W. Qiu, Massachusetts Institute of Technology (United States); P. Rakich, Yale Univ. (United States); H. Shin, Sandia National Labs. (United States); H. Dong, The Univ. of Texas at Austin (United States)

863608 Slow light in dye-doped chiral liquid crystals (Invited Paper) [8636-8]

D. Wei, INLN, CNRS, Univ. de Nice-Sophia Antipolis (France) and Xiamen Univ. (China);

U. Bortolozzo, INLN, CNRS, Univ. de Nice-Sophia Antipolis (France); J. P. Huignard, Jphopto

(France); S. Residori, INLN, CNRS, Univ. de Nice-Sophia Antipolis (France)

863609 Observation of slowed light through a ruby window [8636-9]

E. Wisniewski-Barker, G. Gibson, S. Franke-Arnold, Univ. of Glasgow (United Kingdom);

Z. Shi, Univ. of Rochester (United States); R. W. Boyd, Univ. of Rochester (United States) and Univ. of Ottawa (Canada); M. J. Padgett, Univ. of Glasgow (United Kingdom)

\section{VAPORS}

8636 OC Tunable lossless slow and fast light in a four-level N-system (Invited Paper) [8636-12]

I. Novikova, E. E. Mikhailov, College of William and Mary (United States); L. Stagg, The Univ. of North Carolina at Asheville (United States); S. Rochester, D. Budker, Rochester Scientific LLC (United States) 
8636 OF Dispersion enhancement in atom-cavity and coupled cavity systems (Invited Paper) [8636-15]

D. D. Smith, NASA Marshall Space Flight Ctr. (United States); K. Myneni, U.S. Army Research, Development and Engineering Command (United States); H. Chang, Ducommun Miltec (United States)

PCI

$8636 \mathrm{OH}$ Fast light and quantum correlations from four-wave-mixing in atomic vapor (Invited Paper) [8636-17]

U. Vogl, R. T. Glasser, P. D. Lett, National Institute of Standards and Technology (United States) and Univ. of Maryland (United States)

8636 0J Progress towards atomic vapor photonic microcells: Coherence and polarization relaxation measurements in coated and uncoated HC-PCF (Invited Paper) [8636-19] T. D. Bradley, CNRS, XLim Research Institute, Univ. of Limoges (France) and Univ. of Bath (United Kingdom); J. J. McFerran, CNRS, XLim Research Institute, Univ. of Limoges (France); J. Jouin, CNRS, Ctr. Européen de la Céramique (France); E. llinova, CNRS, XLim Research Institute, Univ. of Limoges (France); P. Thomas, CNRS, Ctr. Européen de la Céramique (France); F. Benabid, CNRS, XLim Research Institute, Univ. of Limoges (France) and Univ. of Bath (United Kingdom)

8636 OK Versatile all-fiber slow-light assisted sensor (Invited Paper) [8636-20]

M. Bravo, Univ. Pública de Navarra (Spain); X. Angulo-Vinuesa, S. Martin-López, Consejo Superior de Investigaciones Científicas (Spain); M. Lopez-Amo, Univ. Pública de Navarra (Spain); M. González-Herráez, Univ. de Alcalá (Spain)

\section{SENSORS I}

8636 OM The solid-state ring laser gyro: current and future trends (Invited Paper) [8636-22]

S. Schwartz, Thales Research \& Technology (France); T. Lauprêtre, F. Goldfarb, F. Bretenaker, Lab. Aimé Cotton, CNRS, Univ. Paris Sud 11 (France); R. Ghosh, Jawaharlal Nehru Univ. (India); I. Carusotto, Univ. degli Studi di Trento (Italy); G. Feugnet, F. Gutty, J.-P. Pocholle, Thales Research \& Technology (France)

8636 ON Brillouin fast-light fiber laser super-sensor (Invited Paper) [8636-23] J. Schever, Tel Aviv Univ. (Israel) and Northwestern Univ. (United States); O. Kotlicky, Tel Aviv Univ. (Israel); S. M. Shahriar, Northwestern Univ. (United States)

$86360 Q \quad$ Fast-light enhanced integrated on-chip laser gyroscope for rotation sensing [8636-26] S. Deng, Z. Xiao, H. Zhang, L. Zhao, A. Huang, Beihang Univ. (China)

PC II

8636 0X Electrically controlled photonic crystal slow light device and its application to optical correlator [8636-33] N. Ishikura, R. Hayakawa, R. Hosoi, M. Shinkawa, H. C. Nguyen, N. Yazawa, T. Baba, Yokohama National Univ. (Japan) 
$8636 \mathrm{OZ}$ Nonlinearity induced ultrafast slow-light tuning in photonic crystal waveguide [8636-35]

K. Kondo, Yokohama National Univ. (Japan); M. Shinkawa, Y. Hamachi, Y. Saito, Y. Arita,

T. Baba, Yokohama National Univ. (Japan) and Japan Science and Technology Agency

(Japan)

\section{QUANTUM OPTICS}

863610 Quantum state tomography of slow and stored light (Invited Paper) [8636-36]

A. M. C. Dawes, N. T. Holte, H. A. Dassonville, Pacific Univ. (United States)

863612 Towards scalable photonics via quantum storage (Invited Paper) [8636-38]

J. Nunn, Oxford Univ. (United Kingdom); N. K. Langford, Royal Holloway Univ. of London

(United Kingdom); W. S. Kolthammer, T. F. M. Champion, M. R. Sprague, P. S. Michelberger, Oxford Univ. (United Kingdom); X.-M. Jin, Oxford Univ. (United Kingdom) and National Univ. of Singapore (Singapore); D. G. England, National Research Council Canada (Canada); I. A. Walmsley, Oxford Univ. (United Kingdom)

863615 Measurement of the velocity of a quantum object: a role of group velocity [8636-41] Y. V. Rostovtsev, Univ. of North Texas (United States)

863616 Propagation of quantum optical fields under the conditions of multi-photon resonances in a coherent atomic vapor [8636-42]

G. Romanov, T. Horrom, I. Novikova, E. E. Mikhailov, College of William and Mary (United States)

\section{SENSORS II}

8636 1C Enhanced sensing in a double-Raman superluminal ring laser (Invited Paper)

[8636-48]

T. Y. Abi-Salloum, Widener Univ. (United States); S. M. Shahriar, Northwestern Univ. (United States)

8636 ID Detecting Coriolis force via slow light (Invited Paper) [8636-49]

S. Davuluri, Y. V. Rostovtsev, Univ. of North Texas (United States)

\section{TELECOM AND NLO}

$8636 \mathrm{lF} \quad$ Wide band optical switch via quantum interference (Invited Paper) [8636-51]

J. XU, The National Ctr. for Mathematics and Physics (Saudi Arabia), Texas A\&M Univ. (United States), and Tongji Univ. (China); M. Al-Amri, The National Ctr. for Mathematics and Physics (Saudi Arabia); M. Zubairy, Texas A\&M Univ. (United States)

$8636 \mathrm{1H}$ Tunable storage of optical data packets modulated in spectrally efficient formats (Invited Paper) [8636-53]

T. Schneider, Hochschule für Telekommunikation Leipzig (Germany) 
863611 Cavity lifetime control by slow-light and nonlinear effects (Invited Paper) [8636-54]

P. Grinberg, P. Hamel, M. Brunstein, K. Bencheikh, A. M. Giacomotti, A. Levenson, Lab. de Photonique et de Nanostructures, CNRS (France); Y. Dumeige, Univ. Européenne de Bretagne and Univ. de Rennes I (France) and FOTON, CNRS (France)

8636 IL Linear and nonlinear optics in photonic crystals (Invited Paper) [8636-57]

I. V. Melnikov, National Research Univ. of Information Technologies, Mechanics and Optics (Russian Federation)

Author Index 


\section{Conference Committee}

Symposium Chair

David L. Andrews, University of East Anglia Norwich (United Kingdom)

Symposium Cochairs

Alexei L. Glebov, OptiGrate Corporation (United States)

Klaus P. Streubel, OSRAM GmbH (Germany)

Program Track Chair

Zameer U. Hasan, Temple University (United States)

Conference Chairs

Selim M. Shahriar, Northwestern University (United States)

Frank A. Narducci, Naval Air Systems Command (United States)

Conference Program Committee

Tony Abi-Salloum, Widener University (United States)

Shanhui Fan, Stanford University (United States)

Daniel Joseph Gauthier, Duke University (United States)

Kohzo Hakuta, The University of Electro-Communications (Japan)

Ortwin Hess, Imperial College London (United Kingdom)

John C. Howell, University of Rochester (United States)

Jacob B. Khurgin, Johns Hopkins University (United States)

Uriel Levy, The Hebrew University of Jerusalem (Israel)

Irina Novikova, The College of William \& Mary (United States)

Gour S. Pati, Delaware State University (United States)

Jacob Scheuer, Tel Aviv University (Israel)

David D. Smith, NASA Marshall Space Flight Center (United States)

Session Chairs

1 Resonators

Philip R. Hemmer, Texas A\&M University (United States)

2 Integrated and Solid-State Optics

Misha Sumetsky, OFS Laboratories (United States) 
3 Vapors

Rupamanjari Ghosh, Jawaharlal Nehru University (India)

$4 \quad \mathrm{PCl}$

Michelle L. Povinelli, The University of Southern California (United States)

5 Sensors I

Luc Thévenaz, Ecole Polytechnique Fédérale de Lausanne (Switzerland)

6 Plasmonics and Metamaterials

Selim M. Shahriar, Northwestern University (United States)

$7 \quad$ PC II

Ortwin Hess, Imperial College London (United Kingdom)

8 Quantum Optics

Jacob B. Khurgin, Johns Hopkins University (United States)

9 Theory

Sean M. Spillane, Los Gatos Research, Inc. (United States)

10 Sensors II

Yunhui Zhu, Duke University (United States)

Daniel Joseph Gauthier, Duke University (United States)

11 Telecom and NLO

Robert W. Boyd, University of Ottawa (Canada) 


\section{Introduction}

The field of slow light began in 1999 with the first demonstration of pulses propagating through an ultracold sodium gas with ultraslow group velocity. Since then, the field has blossomed, with many exciting advances occurring in a wide range of materials, including cold and room temperature gases, optical cavities, photonic crystals, metamaterials, semiconductor materials, and now even computer chips. Shortly after the demonstration of slow light in an ultracold gas, superluminal pulse propagation was demonstrated in a room temperature atomic vapor, and the field of fast light has evolved in parallel to the field of slow light. Now, through various techniques, systems can even be switched between normal and anomalous dispersion, allowing scientists the ability to switch between slow and fast light. The purpose of the 2013 Advances in Slow and Fast Light VI conference was to showcase the many exciting studies and practical applications of slow and fast light from research groups around the world. Talks were presented in several sessions with subjects that included resonators, integrated and solid-state optics, vapors, plasmonics and metamaterials, quantum optics, theory, telecommunications and nonlinear optics, as well as two sessions on photonic crystals, and two sessions on sensors.

The papers contained in the volume are meant to be representative of the work presented at this conference and demonstrate the current breadth of the field. Four quantum optics papers explore some of the more basic questions, such as quantum communication employing quantum storage, quantum tomography, the role of group velocity in the measurement of a quantum object's velocity, and propagation effects. On the more applied side, there are nine papers that come from the telecommunications/nonlinear optics and sensors sessions. These papers include work in tunable optical storage and cavity lifetime control, wideband optical switches and optics in photonics crystals, as well as sensor papers reporting advances in gyroscopes and the measurement of the Coriolis force. Finally, there are papers that fill in the intermediate range between fundamental and applied physics, including reports on slow light in photonic crystals and photonic crystal waveguides, microcells, whispering gallery mode and compact coupled resonators, vapors, microcells, and liquid crystals. All in all, there are twenty-five fascinating papers contained in this volume. 
Neither the conference, nor the papers in this volume are intended to be representative of the wide range of work being done in the fields of slow and fast light, from fundamental studies to applied work. This volume is not exhaustive, but we hope the reader will find it useful.

Frank A. Narducci

Selim M. Shahriar 